\title{
Microsoft Office 365 as an Alternative in Online Learning during the Covid-19 Pandemic
}

\author{
Nurjannah ${ }^{1}$, Irmayanti $^{2}$, Hardianto Rahman ${ }^{3}$, Nurul Islamiah $^{4}$, Anggy Heriyanti $^{5}$ \\ \{nurjannah310807@gmail.com ${ }^{1}$ \} \\ Institut Agama Islam Muhammadiyah Sinjai, 92612, Indonesia ${ }^{1,2,3,4,5}$
}

\begin{abstract}
Covid-19 pandemic requires lecturers to do online learning, so an alternative is needed to support their learning. Microsoft Office 365 is an application that has many features to make the learning process easier. The purpose of this research is to describe the use of Microsoft Office 365 as an online learning alternative during the Covid-19 pandemic. This research is qualitative with a descriptive approach. The research subjects were students of the Islamic Institute of Muhammadiyah Sinjai, Mathematics Education Study Program. Data were collected by distributing questionnaires and conducting interviews. Lecturers use several Microsoft Office 365 features in learning, namely Teams, Forms, and One Drive. Teams are used to create virtual classes, share materials, develop assignments, quizzes, assessments, and virtual meetings. Form is used to generate attendance lists and questions. One Drive is used to store files and share links. As a conclusion, Office 365 can facilitate lecturers in the learning process because it has many features that can be used as an alternative for online learning during the Covid-19 pandemic.
\end{abstract}

Keywords: Microsoft office 365, online learning, covid-19 pandemic

\section{Introduction}

COVID-19 pandemic is a devastating disaster for the entire population of the earth [1]. Coronavirus itself is a large family of viruses that cause diseases with mild to severe symptoms [2]. COVID-19 has been a real test for higher education institutions worldwide in terms of their level of readiness, flexibility, and adaptability in responding to similar global crises [3]. COVID-19 outbreak has created educational disruptions [4]. Many schools in the world were closed to stop the spread of covid-19. Consequently, learning activities of at least 290.5 million students around the globe disrupted [5]. Not only schools but also all universities have been affected by COVID-19. To do all the learning process using the internet

Closing schools requires education to be carried out online because the government prohibits educational institutions from conducting direct learning to avoid direct contact [6][7]. Online learning has been used in various universities, both using fully online of blended learning [8]. However, because of the Covid-19 Pandemic, all learning must be conducted online. Online learning can bring students and lecturers together to doing all the learning process using the internet [9]. Online learning is an open distributed learning system that employs educational tools using the internet and network-based technology to promote learning and knowledge processing through meaningful actions and interactions [10]. 
Although there have been changes in the learning system, online learning has become part of several education systems in the world, however the levels and methods of using this technology aim to achieve quality and varied online learning. This depends on many related factors as well as all parties who are already involved in integrating technology into the education system [11].

Online learning also has the advantage of making students more independent in learning [12]. Online learning is more student-centered, that creates responsibility and autonomy in education [13]. In Indonesia itself, the government provides several applications that support students' learning activities. Educators can also meet students directly through applications that they can access via internet. However, some obstacles in online learning make students less interested. Besides, online learning can increase high interactivity, improve memory, provide a more learning experience by using text, audio, video, and animation to convey information, and also make it easier to obtain, update and download content, send emails to other students, post comments on discussion forums, use chat rooms, and conduct video conferences to communicate directly [10]. Once students can utilize online learning well, their learning outcomes will increase [14].

To get all the features in online learning, students are faced with new problems of having to use many applications which is difficult for them. For example, Google Classroom can only create classes, share material, and ask questions about material via forums. Zoom, Google Meet, and similar applications can only be used for video conferencing without creating a course. Therefore, in order to create classes and conduct video conferences, students and teachers must install several applications. This is quite difficult for lecturers and students, so we need learning alternatives to facilitate online learning. The application to be elaborated is Microsoft Office 365. This application has many features so that teachers and students only need to install this application without installing another application.

Microsoft Office 365 makes it easy for educators to collaborate on document learning and supports online learning processes and evaluations using an internet connection [15]. Office 365 is an online software created by Microsoft to meet users' needs in the office, corporate, and education fields. Especially in education, Microsoft provides Office 365 for free, and some of its features can be used as e-learning so that anyone can use Office 365 anywhere and whenever there are educators who are qualified and skilled to use Office 365 [16].

\section{Method}

This research is qualitative with a descriptive approach. The subjects were 37 students of 7th Semester in Mathematics Education Study Program and 1 lecturer of Islamic Institute of Muhammadiyah Sinjai. There are two data collection methods used in this study, questionnaire and interview methods. The questionnaire is given in the form of an online questionnaire with Microsoft form, and the interview is conducted online. To test the validity researchers employed data triangulation. The analysis was carried out in 4 stages, including 1) collection; 2) reduction; 3) displaying, and 4) conclusion. 


\section{Results and Discussion}

\subsection{Lecturers' perceptions in using microsoft office 365}

Based on observations, a lecturer who teaches Mathematics at Islamic Institute of Muhammadiyah Sinjai has a Microsoft office 365 account with iaimsinjai.ac.id domain. This campus organizational domain enables the lecturers to communicate and collaborate without boundaries. Besides, this application can facilitate distance learning during a pandemic because it has many features. The features often used in education are Teams, One Note, One Drive, Sway, PowerPoint, Excel and Word Online, Forms. Teams allow you to conduct virtual meetings as well as assign and grade student assignments. One note is used to create a virtual learning module. One drive is used to store and share learning material links. Sway to make presentations interactive and engaging. PowerPoint, Excel, and Word are like office 2019 uses, but these features allow us to complete tasks collaboratively because we can share links for editing. Lastly, Form is used to create attendance lists that can directly be embedded in Excel. Form can also be used to develop questions for daily assignments or final exams.

Based on the interview with one of the lecturers, the features can be integrated into each other. For example, making a presentation using the Sway feature can be combined with the Form. After the presentation is complete, students can go directly to the Form to complete tasks related to the presentation material. Besides, these features can be integrated with other applications such as YouTube, Kahoot, and Quizizz. This facilitates the process of online learning during the Covid-19 pandemic and is effectively used in learning, especially mathematics learning. Learning using the Microsoft office 365 is feasible to be applied in the learning process in the classroom [17].

\subsection{Students' perceptions of the use of microsoft office 365}

Based on the results of observations, all students of 7th semester Mathematics Education in Islamic Institute of Muhammadiyah Sinjai have a Microsoft office 365 account with iaimsinjai.ac.id domain. Microsoft office 365 has many features that can be used in learning. Based on the results of interviews, the features that are often used in learning are Teams, Forms, One Note, One Drive, Sway, Word, Excel, and PowerPoint. Teams are used to attend virtual meetings, answer questions directly given by the lecturer, and check assignment scores from their lecturer. With the One-note feature, students can access the digital module anytime, anywhere. One drive can be used to store files/learning materials and assignments. Sway can be used to create interactive and engaging presentations. Word, Excel, and PowerPoint allow students to collaborate on tasks by simply sending a link to a group of friends.

According to one student, using Office 365 application can make learning easier than using another application because it is easier to access materials and assignments. Besides, this application is very easy because it can be accessed by Android anytime and anywhere. Microsoft Teams for Education application is very good to increase students' interest in learning [18].

\subsection{Discussion}

Lecturers and students perceive that Office 365 in online learning is effective to be employed during the Covid-19 pandemic. Microsoft Office 365 application has a quality that Microsoft Office 2019 does not, which is that it can be accessed online. Its features are always up to date. This application has $1 \mathrm{~TB}$ of cloud storage so it can store data anytime and from 
anywhere more simply without having to use a flash drive. This application can facilitate the teaching and learning process and can increase student motivation. This is reinforced by the results of research that the design of e-learning using office 365 and its application can increase students' interest, insight, and motivation to learn and contribute to the advancement of current knowledge [19]. This is in line with the research that motivation and self-efficacy affect mathematics achievement of Primary Teacher Education Program (PGSD and PGMI) students [20]. Therefore, a lecturer must be able to deliver lessons with engaging strategies and applications in order to increase students' motivation in learning during the pandemic. Based on observations and subject interviews, the Office 365 application has many interesting features that can be integrated into each other in learning. This application allows lecturers and students to have virtual meetings, communicate directly and be able to collaborate in completing assignments.

\section{Conclusion}

Microsoft Office 365 is an alternative in online learning during a pandemic because it has many features that can be integrated. The elements often used in learning at IAI Muhammadiyah Sinjai, especially the 7th semester Mathematics Education Study Program, are Teams, One Note, One Drive, Sway, Word, Excel, and online PowerPoint. All of these features make learning easy and can be accessed via Android limitless and paperless.

\section{Acknowledgements}

We would like to thank all those involved in this research. These included the leadership of the Islamic Institute of Muhammadiyah Sinjai who had funded this research, mathematics education lecturers, and students who were willing to become research subjects. Thank you very much for your help.

\section{References}

[1] R. H. Syah, "Dampak Covid-19 pada Pendidikan di Indonesia: Sekolah, Keterampilan, dan Proses Pembelajaran,” SALAM J. Sos. dan Budaya Syar-i, 2020, doi: 10.15408/sjsbs.v7i5.15314.

[2] W. A. F. Dewi, "Dampak COVID-19 terhadap Implementasi Pembelajaran Daring di Sekolah Dasar,” EDUKATIF J. ILMU Pendidik., 2020, doi: 10.31004/edukatif.v2i1.89.

[3] M. E. T. Osman, "Global impact of COVID-19 on education systems: the emergency remote teaching at Sultan Qaboos University," J. Educ. Teach., 2020, doi: 10.1080/02607476.2020.1802583.

[4] Onyema; Eucheria; Obavemi, "Impact of Coronavirus Pandemic on Education. Journal of Education and Practice," J. Educ. Pract., 2020.

[5] Mastura and R. Santaria, "Dampak Pandemi Covid-19 terhadap Proses Pengajaran bagi Guru dan Siswa," J. Stud. Guru dan Pembelajaran, 2020.

[6] I. Anshori and U. Illiyyin, "DAMPAK COVID-19 TERHADAP PROSES PEMBELAJARAN DI Mts Al-ASYHAR BUNGAH GRESIK," Islam. Manag. J. Manaj. Pendidik. Islam, 2020.

[7] F. Firman and S. Rahayu, "Pembelajaran Online di Tengah Pandemi Covid-19," Indones. J. Educ. Sci., 2020, doi: 10.31605/ijes.v2i2.659. 
[8] S. S. Adji and S. Hamda, "Utilization of Learning Analytic on Measuring Student Participation in Online Learning," in Journal of Physics: Conference Series, 2019, doi: 10.1088/17426596/1280/3/032014.

[9] E. Kuntarto, "Keefektifan Model Pembelajaran Daring Dalam Perkuliahan Bahasa Indonesia di Perguruan tinggi," J. Indones. Lang. Educ. Lit., 2017.

[10] N. Arnesti and A. Hamid, "PENGGUNAAN MEDIA PEMBELAJARAN ONLINE - OFFLINE DAN KOMUNIKASI INTERPERSONAL TERHADAP HASIL BELAJAR BAHASA INGGRIS," J. Teknol. Inf. Komun. DALAM Pendidik., 2015, doi: 10.24114/jtikp.v2i1.3284.

[11] Duraku; Zamira Hyseni \& Nagavei; Mirjeta, "The Impact Of The Covid-19 Pandemic on The Education of Children with Disabilities," Soc. Word Educ., 2020.

[12] A. Sadikin and A. Hamidah, "Pembelajaran Daring di Tengah Wabah Covid-19:(Online Learning in the Middle of the Covid-19 Pandemic)," BIODIK J. Ilm. Pendidik. Biol., 2020.

[13] Y. C. Kuo, A. E. Walker, K. E. E. Schroder, and B. R. Belland, "Interaction, Internet self-efficacy, and self-regulated learning as predictors of student satisfaction in online education courses," Internet High. Educ., 2014, doi: 10.1016/j.iheduc.2013.10.001.

[14] R. Bayu Putra, Elfiswandi, M. Ridwan, S. Rizki Mulyani, D. Syahrullah Ekajaya, and R. Andhika Putra, "Impact of Learning Motivation, Cognitive and Self-Efficacy in Improving Learning Quality E-Learning in Industrial Era 4.0," in Journal of Physics: Conference Series, 2019, doi: 10.1088/17426596/1339/1/012081.

[15] G. Amirullah, "Pelatihan Pengembangan Kelas Digital Berbasis Microsoft 365 di Sekolah Muhammadiyah DKI Jakarta,” Community Dev. J., vol. 1, no. 3, pp. 223-227, 2020.

[16] Suprianto, "Perancangan E-Learning Menggunakan Office 365 Dalam Proses Belajar Mengajar," Semin. Nas. R., 2018.

[17] R. E. P. S. B. Maisyarah, "Efektivitas Penerapan Aplikasi Microsoft Office Pembelajaran Akuntansi di Kelas X SMK," J. Pendidik. dan Pembelajaran Untan, vol. 5, no. 9, 2016.

[18] A. S. Situmorang, "Microsoft Teams for Education Sebagai Media Pembelajaran," Microsoft Teams Educ. Sebagai Media Pembelajaran Interaktif Meningkat. Minat Belajar, 2020.

[19] W. E. Susanto and Y. G. A. Ayu, "Perancangan E-Learning Berbasis Web Pada SMP Negeri 3 Patuk Gunungkidul Yogyakarta," Bianglala Inform., 2017.

[20] S. Hamdi and A. M. Abadi, "PENGARUH MOTIVASI, SELF-EFFICACY DAN LATAR BELAKANG PENDIDIKAN TERHADAP PRESTASI MATEMATIKA MAHASISWA PGSD STKIP-H DAN PGMI IAIH,” J. Ris. Pendidik. Mat., 2014, doi: 10.21831/jrpm.v1i1.2666. 